\section{Hydro-Electric Power Development in Scotland}

A PAPER on "Scottish Hydro-Electric Stations" by Mr.W.T.Halcrow, read on September 12 before Section G (Engineering) of the British Association at Aberdeen, provides an interesting account of the present state and future potentialities of hydro-electric power development in Scotland. Mr. Halcrow, whose paper appears in Engineering of September 14, commences by quoting from the final report (1921) of the Water Power Resources Committee the estimates of power available in the British Isles, which assign to Scotland $217,965 \mathrm{kw}$., to Ireland 113,000 kw., and to England and Wales $56,340 \mathrm{kw}$., making a total of $387,305 \mathrm{kw}$. of continuous output. These figures, being based on preliminary studies and imperfect information, will probably be considerably exceeded in actual realisation. A brief summary is given of the principal developments in Scotland at the present date, in which it is shown that schemes in operation or under construction amount to $169,700 \mathrm{kw}$. and proposed schemes to $155,600 \mathrm{kw}$., making a total of $325,300 \mathrm{kw}$. It is pointed out that in the Highlands there is a large number of lochs up to 1,200 ft. above sea-level, most of which can be readily adapted as storage reservoirs, and this fact, coupled with the suitability of the topographical features and the high average annual rainfall, makes this part of the country eminently suitable for the development of waterpower.

There are three main types of water-power development in Scotland: (1) those with a fully regulated flow from the catchment area, giving a continuous output at 90-100 per cent load factor, and generally supplying power to a factory employing electro-metallurgical or other continuous process; (2) those with a fully regulated flow, but working on a much lower load factor, and used for supplying power for general purposes; and (3) those with a partially regulated flow, and having little or no storage. These three types have separate and distinct characteristics, and examples of each are cited, including in the first class the Lochaber installation with the realisation of which $\mathrm{Mr}$. Halerow and his firm have been associated. There is, finally, a brief consideration of the relative advantages of steamand water-power stations, from which Mr. Halcrow concludes that "notwithstanding the handicap of heavy initial expenditure, it is found that the cost per unit generated by water is less than by steam in stations of similar capacity".

\section{Daylight Meteor}

ON September 14 at about a quarter to four in the afternoon, a meteor was seen by a number of observers in the south and east of England. Perhaps the most accurate report is that given by $\mathrm{Mr}$. Cullen, of the staff of the Royal Observatory at Greenwich, who went out into the courtyard to read the thermometers after observing the transit of Arcturus, the afternoon being a very clear one with a bright blue sky and sunshine. Mr. Cullen's attention was attracted by a bright object rocket-like in appearance, leaving a trail and having a very bright nucleus. The object descended at an angle of about $40^{\circ}$ to the horizon : it was seen over an arc of from $15^{\circ}$ to $20^{\circ}$, and lasted two or three seconds. The meteor disappeared as if exploding into two bright objects, but no noise was heard. The approximate position of disappearance was R.A. $19 \mathrm{hr}$. 0 min., Dec. $0^{\circ}$. While Mr. Cullen considers this position rough, there can be no doubt whatever about the observer's longitude and his latitude is tolerably well known. The approximate sidereal time of the phenomenon was $14 \mathrm{~h} .17 \mathrm{~m} .5 \mathrm{~s}$. The area over which the object was seen seems to have extended to Cromer in the north, the Isle of Wight in the south, and Weston-super-Mare and Kent on the west and east respectively.

\section{Archæological Finds from Egypt and Samaria}

Two exhibitions illustrating the results of the past season's excavations at Tell el-Amarna on behalf of the Egypt Exploration Society, and at Samaria for the Palestine Exploration Fund and other bodies, are being held at the rooms of the Palestine Exploration Fund, 2 Hinde Street, Manchester Square, London, W, on September 17-October 13. Among the exhibits from Tell el-Amarna are perspective views of the Great Temple, upon the exploration of which the expedition has been engaged recently. They have been constructed on the basis of the remains of the temple as they have now been revealed, and show the position of the votive tables and other arrangements of the temple. A remarkable sculptured sandstone head, life-like in quality, is believed to be a representation of Smenkhkara, co-regent with Akenaton. From the police head-quarters of the city come a large number of antiquities, including amulets and rings of glazed glass paste, clay moulds from which jewellery was made and numerous fragmerts of inscribed wine-jars. From the 'record office', clay tablets inscribed in Babylonian cuneiform and a list of scribes were obtained. The exhibition includes minutely accurate copies on ivory of the Tutankhamen jewellery by Mrs. Winifred Brunton and paintings by Miss A. M. Calverley and Miss M. F. Broome of the reliefs, paintings and inscriptions of the tomb of Seti I, showing the progress of the great undertaking of the complete record of material of this tomb which is being carried out by the Society in co-operation with the Oriental Institute of Chicago and with the financial assistance of Mr. John D. Rockefeller, Jr.

THE exploration of the city of Samaria, a joint undertaking in which Palestine, the United States and Great Britain are participating, has now been in progress for three years. Among the more important discoveries have been the Temple of Herod, contemporary with Augustus, and part of a building of the 9-8th century B.c., which is believed to be Ahab's 'House of Ivory'. Among recent finds from the latter are a number of cosmetic jars, some of which still show the smear of paint, green and blue. A further addition is made to the remarkable collection of inlay ivory carvings characteristic of the site at this period, which is now of particular interest in view of 